\title{
Prenatal Diagnosis of Sacrococcygeal Teratomas; Case Report
}

\author{
Sakrokosigeal Teratomun Prenatal Tanısı; Olgu Sunumu
}

Tuncay Yüce ${ }^{1}$, Müge Keskin'1, Mehmet Murat Seval' ${ }^{1}$ Acar Koç ${ }^{1}$

Ankara Üniversitesi Tıp Fakültesi Kadın Hastalıkları ve Doğum AD.

Sacrococcygeal teratomas are the most common tumors among newborns. Incidence of SCT ranges
between $1 / 35000$ and $1 / 40000$. Not only the tumor's vascularity but also the accompanying
placentomegaly, polyhidramnios and fetal hidrops are the main predictors of fetal outcome. Here we
describe our experience of a 22 weeks and 3 days pregnancy complicated with a fetal sacrococcygeal
teratoma accompanied with cardiac sequale. In our case SCT was measured $80 x 78 \times 72$ mm (cranio caudal x
transverse x antero posterior) in size. After appropriate counselling pregnancy was terminated.
Key Words: Sacrococcygeal Teratomas, Prenatal Diagnosis, Pregnancy Termination
Sakrokoksigeal teratom yenidoğanlarda sık görülen bir tümördür. İnsidansı $1 / 35000$ ile $1 / 40000$
arasındadır. Fetal sonucu belirleyen faktörler tümörün damarlanmasına ek olarak mevcut plasentomegali,
polihidroamniyoz ve fetal hidropsdur. Bizim sunduğumuz olgu 22 hafta 3 günlük gebeliği tespit edilen
büyük bir sakrokoksigeal teratoma eșlik eden fetal kalp yetmezliği olgusudur. SCT $80 x 78 \times 72$ mm
(kraniokaudal x transvers x anteroposterior) boyutlarında ölçülmüștür. Daha sonra durum hasta ile
paylașılarak gebelik sonlandırılmıștır.
Anahtar Sözcükler: Sakrokoksigeal Teratom, Prenatal Tanı, Gebelik Sonlandırma

Fetal tumors are rare and approximately in half of the cases they present as sacrococcygeal teratomas (SCT). Incidence of SCT is $1 / 35000$ $1 / 40000$. It's more common among females $(1,2)$. Sacrococcygeal teratomas are the most common tumors among newborns as well. Sacrococcygeal teratomas originates from 3 germinal layers. It arises from the pluripotent cell lines in Hensen's node, located on the anterior surface of the sacrum or the coccyx $(3,4)$. Altman classification divides sacrococcygeal teratomas in 4 groups according to its location and components. Although the classification of Altman is descriptive, it has no prognostic value. Recently necessity for a new prognostic classification has been emphasized (5). Benachi A and his friends (6) suggested that it's possible to classify fetal SCT into 3 groups regarding to size, evolution rate and vascularity. Placentomegaly, polyhydramnios, accompanying fetal hydrops in addition to vascularity of the tumor itself are the main predictors of the perinatal outcome (7). This report describes our experience about a case of SCT

\section{CASE}

A 42 year old patient, gravida 4 parity 2 , with a gestation of 22 weeks and 3 days was referred to our clinic for ultrasound from an obstetrics and gynecology specialist due to a mass noticed during routine fetal examination. Anomaly was not detected previously during patient's sonography performed either at first trimester or second trimester. A 2D ultrasound was performed with the transducer of Voluson E6 ( GE Healthcare Austria GmbH, Zipf, Austria). Sonography revealed a sacrococcygeal teratoma extending inferiorly from the sacrum composed of cystic and soft tissue components measuring 80x78x72 $\mathrm{mm}$ (cranio caudalxtransversexantero posterior) with accompanying demised lung maturation and increased cardiothoracic ratio (Figure 1). Due to tumor's large size and accompanying sequales of lungs and heart, poor prognosis was estimated. Sonographic description of the relationship between the mass and fetus provided a better understanding of this anomaly for the parents. After

\footnotetext{
Fax: +9031232035 53

E-mail: drtuncayyuce@gmail.com

Department of Obstetrics and Gynecology Ankara Turkey

Corresponding Author

Tuncay Yüce, M.D.
} 